\title{
SIFAT ORGANOLEPTIK, KANDUNGAN ZAT GIZI, DAN DAYA TERIMA IWEL LATAN UNTUK MAKANAN TAMBAHAN IBU HAMIL
}

\author{
Zuhria Handayani. ${ }^{1 *}$, Made Darawati. ${ }^{1}$, I Gde Narda Widiada ${ }^{1}$ \\ Jurusan Gizi, Poltekkes Kemenkes Mataram, Indonesia \\ Jalan Praburangkasari Dasan Cermen Sandubaya Kota Mataram \\ *Email Korespondensi : zuhriahandayani97@gmail.com
}

\begin{tabular}{l}
\hline \hline Article Info \\
\hline Article history: \\
Received January $16^{\text {th }}, 2019$ \\
Revised February $23^{\text {th }}, 2019$ \\
Accepted March $18^{\text {th }}, 2019$ \\
\hline
\end{tabular}

Keyword:

Iwel Latan, Organoleptic

Proprties, Soy Flour

\begin{abstract}
Background :In Indonesia there are still many cases of Chronic Energy Deficiency caused by imbalance of nutrients, especially in energy and protein intake, so that the nutrients needed by the body are not fulfilled. Efforts that can be done to prevent chronic energy shortages in pregnant women is to provide alternative food supplements in the form of nutrient dense snacks, one of which is iwel which is added with high-protein legumes namely soybeans which are then made into soy flour. Iwel with the addition of soybean flour is expected to meet the requirements as PMT for pregnant women. Iwel is a traditional food that is popular with many people, has a soft texture like dodol and is classified as semi-wet food. This study aims to determine the organoleptic properties, nutrient content, and acceptability of Iwel Latan for pregnant women.

Research Methods:The experimental research method with a completely randomized one-factor design, namely the addition of soy flour consisting of 5 treatment levels 10\%, 15\%, 20\%, 25\%, 30\%.

Research result:The results showed that Iwel Latan with the addition of $25 \%$ (t4) soybean flour from the weight of the entire selected ingredient to the best treatment level and the addition of soy flour significantly affected the texture of Iwel Latan ( $p<0.005)$. The content of Iwel Latan nutrients is $40.71 \%$ moisture content, $1.60 \%$ ash content, 9.39\% protein, $3.89 \%$ fat, and $44.40 \%$ carbohydrate.

Conclusion: The nutrient content of Iwel Latan is higher when compared to PMT biscuits which are usually given to pregnant women Chronic Energy Deficiency.The acceptance of pregnant women is 30 people, of which 25 pregnant women receive well (83\%) and 5 pregnant women receive less $(17 \%)$.
\end{abstract}

Copyright (C) JurnalGizi Prima All rights reserved

\section{PENDAHULUAN}

Kurang Energi Kronis adalah keadaan dimana seseorang mengalami kekurangan zat gizi berupa energi dan protein yang berlangsung lama atau menahun. Kurang Energi Kronis sering dijumpai pada Wanita Usia Subur dan Ibu Hamil. Seseorang dikatakan menderita Kurang Energi Kronis apabila LILA berukuran $<23.5$ cm (Supariasa, 2012). Data Riskesdas (2018) mencatat ibu hamil KEK di Nusa Tenggara Barat (NTB) adalah 19,10\%. Data PSG (2017) menunjukkan bahwa persentase ibu hamil yang beresiko KEK pada Provinsi NTB yaitu sebesar 17,4\%. (Kemenkes RI,2018)

Mengingat dampak kurang gizi yang sangat luas, maka perlu upaya penanggulangan masalah kurang energi kronis melalui pemberian makanan tambahan. PMT bagi ibu hamil KEK dimaksudkan sebagai makanan tambahan, bukan sebagai pengganti makanan utama. Makanan tambahan diberikan sekali sehari selama 90 hari berturut-turut, berbasis makanan lokal, dapat diberikan makanan keluarga, atau atau makanan kudapan lainnya. (Kemenkes RI, 2012). 
Pemberian makanan tambahan berfokus pada zat gizi makro dan mikro bagi ibu hamil sangat diperlukan dalam rangka pencegahan Berat Bayi Lahir Rendah (BBLR) dan balita pendek (stunting). Pemberian makanan tambahan ditujukan kepada kelompok sasaran rawan gizi yaitu ibu hamil dengan resiko kurang energi kronis dengan hasil pengukuran LILA <23,5 cm. (Kemenkes RI, 2017).

Selama ini, pemberian makanan tambahan untuk ibu hamil hanya berupa biskuit pabrikan, sehingga untuk menghindari kebosanan dari PMT pabrikan perlu dilakukan penelitian tentang makanan tambahan bagi ibu hamil yang bersifat lokal namun padat akan zat gizi berupa jajan tradisional Iwel. Iwel merupakan jajanan tradisional yang memiliki rasa yang manis dan legit dan digolongkan sebagai makanan semi basah. Terpilihnya Iwel karena jajan tradisional ini cukup digemari dari semua golongan umur karena rasanya yang manis. Bahan iwel adalah tepung beras ketan, kelapa, dan gula.

Peningkatan zat gizi dalam Iwel dilakukan dengan menambahkan kacang-kacangan berupa kacang kedelai yang tinggi akan protein yang kemudian dibuat menjadi tepung kedelai. Ditambahkan juga labu kuning untuk meningkatkan cita rasa. Penggunaan tepung kedelai pada Iwel yang berbahan dasar tepung ketan ini yang kemudian disebut sebagai Iwel Latan (kedelai dan ketan).

Penambahan tepung kedelai dalam Iwel Latan karena kedelai memiliki kandungan gizi yang tinggi diantara kacang-kacangan lainnya. Selain itu, kadar protein kedelai memang paling tinggi yaitu 40,4 g dalam $100 \mathrm{~g}$ bahan makanan (Mahmud dkk, 2009). Labu kuning dalam pembuatan Iwel Latan digunakan untuk memperkaya cita rasa dan nilai gizi. Labu kuning merupakan salah satu bahan makanan yang kaya akan vitamin yaitu betakaroten.

Kedelai merupakan salah satu bahan pangan dari kelompok biji-bijian yang menghasilkan sumber protein (asam amino) serta asam lemak yang penting peranannya dalam kehidupan. Bubuk kedelai dibuat melalui beberapa proses seperti tahapan perendaman, pembersihan, pencucian, penirisan, penjemuran, penggilingan dan pengayakan sehingga menjadi bubuk tepung (Rani dkk, 2013). Berdasarkan penelitian pendahuluan sebelumnya, telah dilakukan percobaan pembuatan iwel latan dengan penambahan tepung kedelai sebanyak $20 \%$ dari berat total bahan, dihasilkan iwel dengan rasa yang manis dan legit, dengan aroma khas yang dihasilkan dari penambahan tepung kedelai.

Berdasarkan latar belakang tersebut, perlu dilakukan penelitian tentang sifat organoleptik, kandungan zat gizi, dan daya terima Iwel Latan berbahan pangan lokal yang diharapkan nantinya dapat meningkatkan nilai ekonomis serta kandungan enrgi dan protein dalam produk tersebut sehingga dapat dijadikan produk makanan yang memiliki daya terima yang tinggi serta dalam perkembangannya dapat menjadi salah satu pilihan makanan untuk makanan tambahan bagi ibu hamil.

\section{METODE PENELITIAN}

\section{Desain Penelitian}

Penelitian ini menggunakan metode Eksperimental di laboratorium dengan rancangan percobaan berupa Rancangan Acak Lengkap (RAL) satu faktor yaitu penambahan tepung kedelai (t) yang terdiri dari 5 aras perlakuan yaitu penambahan tepung kedelai 10\%, 15\%, 20\%, 25\%, 30\% dari berat total keseluruhan bahan. Waktu penelitian dilaksanakan pada bulan Desember 2018. Uji organoleptik dilakukan di laboratorium Ilmu Teknologi Pangan Poltekkes mataram, uji proksimat dilakukan di laboratorium Pusat Studi Pangan dan Gizi Universitas Gadjah Mada. Daya terima oleh ibu hamil dilakukan di Desa Terong Tawah. Adapun tabel formula yang digunakan dalam Iwel Latan dapat dilihat pada Tabel 1.

Tabel 1. Formula Pembuatan Iwel Latan

\begin{tabular}{|c|c|c|c|c|c|c|}
\hline \multirow{2}{*}{ No } & \multirow{2}{*}{ Bahan } & \multicolumn{5}{|c|}{ Perlakuan } \\
\hline & & $\mathbf{t 1}$ & $\mathbf{t 2}$ & t3 & $\mathbf{t 4}$ & $\mathbf{t 5}$ \\
\hline 1 & Tepung beras ketan $(\mathrm{g})$ & 40 & 40 & 40 & 40 & 40 \\
\hline 2 & Tepung kedelai $(\%)$ & 10 & 15 & 20 & 25 & 30 \\
\hline 3 & Labu kuning (g) & 15 & 15 & 15 & 15 & 15 \\
\hline 4 & Gula merah (g) & 20 & 20 & 20 & 20 & 20 \\
\hline 5 & Kelapa parut (g) & 20 & 20 & 20 & 20 & 20 \\
\hline 6 & Gula pasir $(\mathrm{g})$ & 4 & 4 & 4 & 4 & 4 \\
\hline 7 & Garam $(\mathrm{g})$ & 1 & 1 & 1 & 1 & 1 \\
\hline
\end{tabular}

Keterangan: Persentase penambahan tepung kedelai berdasarkan dari berat keseluruhan bahan/ berat total.

\section{Alat dan Bahan Penelitian}


Alat yang digunakan dalam pembuatan Iwel Latan adalah waskom, timbangan bahan makanan, mangkok, dandang, cawan, panci. Alat yang digunakan dalam uji sifat organoleptik adalah lepekan, formulir uji hedonik, kertas tempel, dan bolpoint. Alat yang digunakan dalam uji proksimat adalah Oven, neraca analitik, desikator, botol timbang, alat penyuling, pemanas listrik, labu ukur, beaker gelas, buret, batu didih, alat soxhlet, Erlenmeyer. Bahan yang digunakan dalam pembuatan Iwel Latan adalah tepung beras ketan, labu kuning, tepung kedelai, gula merah, kelapa parut, gula dan garam. Bahan yang digunakan dalam uji sifat organoleptik adalah produk Iwel Latan dan air mineral. Bahan yang digunakan dalam uji proksimat adalah produk Iwel Latan. Bahan yang digunakan untuk uji daya terima adalah produk Iwel Latan.

\section{Cara Pengolahan dan Analisis Data}

Data yang diperoleh dari hasil pengamatan disajikan dalam tabel. Untuk mengetahui sifat organoleptik (warna, aroma, tekstur, rasa) dari setiap penambahan tepung kedelai pada Iwel Latan diolah dan dianalisis dengan menggunakan analisis statistik One Way Anova pada tingkat kepercayaan $95 \%(\alpha=0,005)$. Analisis statistik ini dilakukan dengan menggunakan software program SPSS. Apabila $p<\alpha 0,005$ maka ada pengaruh signifikan dan sebaliknya. Jika ada pengaruh yang signifikan, data dianalisis lebih lanjut menggunakan uji Duncan untuk melihat perlakuan mana yang menyebabkan perbedaan.

\section{HASIL PENELITIAN}

\section{Sifat Organoleptik}

Uji sifat organoleptik menggunakan panelis agak terlatih yaitu mahasiswa gizi Poltekkes Kemenkes Mataram semester VII. Nilai rata-rata dan signifikansi hasil uji organoleptik Iwel Latan dengan penambahan tepung kedelai dengan menggunakan panelis agak terlatih sebanyak 25 orang dapat dilihat Tabel 2.

Tabel 2. Nilai Rata-Rata dan Signifikasi Pengaruh Penambahan Tepung Kedelai Terhadap Sifat Organoleptik Iwel Latan Menggunakan Panelis Agak Terlatih.

\begin{tabular}{ccc}
\hline Parameter & P (Value) & Notasi \\
\hline Warna & 0,965 & NS \\
Aroma & 0,127 & NS \\
Tekstur & 0,004 & S \\
Rasa & 0,989 & NS \\
Overall & 0,089 & NS \\
\hline
\end{tabular}

Sumber: Data primer 2019

Keterangan: $\quad$ NS $=$ Non Signifikan : Tidak Berbeda Nyata

$\mathrm{S}=$ Signifikan : Berbeda Nyata

Berdasarkan Tabel 2. dapat dilihat bahwa untuk parameter warna, aroma, dan rasa memiliki nilai $\mathrm{p}>0.05$. Hal ini menunjukkan bahwa dengan penambahan tepung kedelai tidak memiliki pengaruh yang bermakna terhadap warna, aroma, dan rasa. Iwel Latan untuk parameter tekstur memiliki nilai $\mathrm{p}<0.05$ hal ini menunjukkan bahwa penambahan tepung kedelai memiliki pengaruh yang bermakna terhadap tekstur.

Tabel 3. Nilai Rata-Rata Hasil Uji Organoleptik Terhadap Warna Iwel Latan

\begin{tabular}{cc}
\hline $\begin{array}{c}\text { Perlakuan Penambahan Tepung Kedelai dari } \\
\text { Berat Keseluruhan Bahan }\end{array}$ & $\begin{array}{c}\text { Rata-rata Hasil Uji Organoleptik } \\
\text { Warna Iwel Latan }\end{array}$ \\
\hline t1 $(10 \%)$ & 3,56 \\
t2 $(15 \%)$ & 3,56 \\
t3 $(20 \%)$ & 3,56 \\
t4 $(25 \%)$ & 3,68 \\
t5 $(30 \%)$ & 3,52 \\
\hline
\end{tabular}

Sumber: Data primer 2019

Warna Iwel Latan dengan penambahan tepung kedelai mempunyai nilai rata-rata dengan aras perlakuan t1 sampai t5 yaitu 3,52 sampai 3,68 yang termasuk dalam kategori suka. Warna yang dihasilkan dari setiap aras perlakuan sama yaitu berwarna hitam dengan bintik coklat. Berdasarkan rata-rata tingkat kesukaan terhadap warna, perlakuan yang paling disukai adalah t4. Warna dari setiap aras perlakuan Iwel Latan dapat dilihat pada Gambar 1. 


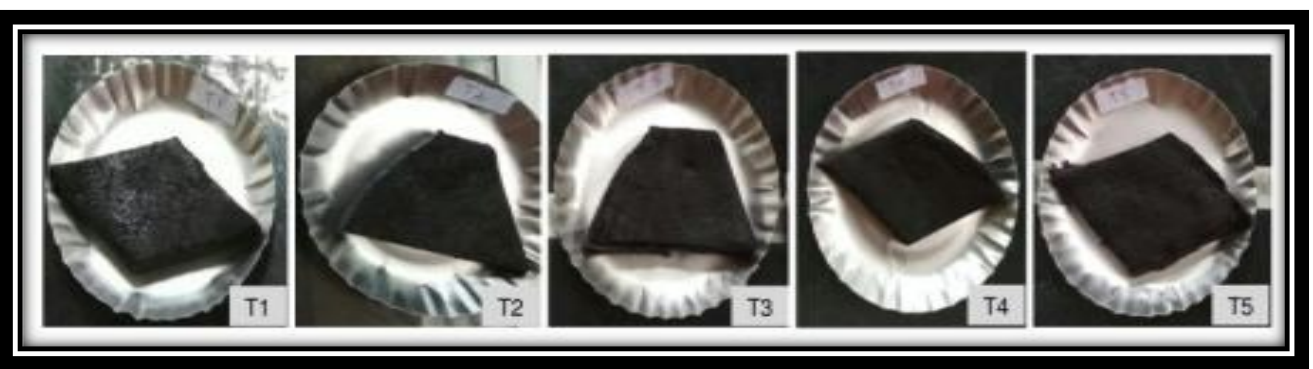

Gambar 1. Iwel Latan

Tabel 4. Nilai Rata-Rata Hasil Uji Organoleptik Terhadap Aroma Iwel Latan

\begin{tabular}{cc}
\hline $\begin{array}{c}\text { Perlakuan Penambahan Tepung Kedelai dari } \\
\text { Berat Keseluruhan Bahan }\end{array}$ & $\begin{array}{c}\text { Rata-rata Hasil Uji Organoleptik } \\
\text { Aroma Iwel Latan }\end{array}$ \\
\hline t1 $(10 \%)$ & 3,16 \\
t2 $(15 \%)$ & 3,48 \\
t3 $(20 \%)$ & 3,32 \\
t4 $(25 \%)$ & 3,52 \\
t5 (30\%) & 2,96 \\
\hline
\end{tabular}

Sumber: Data primer 2019

Aroma Iwel Latan dengan penambahan tepung kedelai mempunyai nilai rata-rata dengan aras perlakuan t1 sampai t5 yaitu 2,96 sampai 3,52 yang termasuk dalam kategori agak suka sampai suka. Aroma yang dihasilkan dari setiap aras perlakuan sama, yaitu aroma khas dari penambahan tepung kedelai yang membuat aroma iwel latan berbeda dari iwel pada umumnya. Berdasarkan rata-rata tingkat kesukaan terhadap aroma perlakuan yang paling disukai adalah $\mathrm{t} 4$.

Tabel 5. Nilai Rata-Rata Hasil Uji Organoleptik Terhadap Tekstur Iwel Latan

\begin{tabular}{ccc}
\hline $\begin{array}{c}\text { Perlakuan Penambahan Tepung } \\
\text { Kedelai dari Berat Keseluruhan } \\
\text { Bahan }\end{array}$ & $\begin{array}{c}\text { Rata-rata Hasil Uji Organoleptik } \\
\text { Tekstur Iwel Latan }\end{array}$ & Notasi \\
\hline t1 $(10 \%)$ & 3,48 & $\mathrm{bc}$ \\
t2 $(15 \%)$ & 3,64 & $\mathrm{bc}$ \\
t3 $(20 \%)$ & 3,20 & $\mathrm{ab}$ \\
t4 $(25 \%)$ & 3,68 & $\mathrm{c}$ \\
t5 $(30 \%)$ & 2,96 & $\mathrm{a}$ \\
\hline
\end{tabular}

Sumber: Data primer 2019

Tekstur Iwel Latan dengan penambahan tepung kedelai diketahui bahwa aras perlakuan $\mathrm{t} 4$ mendapatkan skor untuk parameter tekstur sebesar 3,68 yaitu termasuk dalam kategori suka. Tekstur yang dihasilkan dari setiap aras perlakuan berbeda. Semakin banyak penambahan tepung kedelai, tekstur iwel latan menjadi semakin kompak dan lembut. Berdasarkan rata-rata tingkat kesukaan terhadap tekstur, perlakuan yang paling disukai adalah $\mathrm{t} 4$.

Tabel 6. Tabel Rata-Rata Hasil Uji Organoleptik Terhadap Rasa Iwel Latan

\begin{tabular}{cc}
\hline $\begin{array}{c}\text { Perlakuan Penambahan Tepung Kedelai dari } \\
\text { Berat Keseluruhan Bahan }\end{array}$ & $\begin{array}{c}\text { Rata-rata Hasil Uji Organoleptik Rasa } \\
\text { Iwel Latan }\end{array}$ \\
\hline t1 $(10 \%)$ & 3,40 \\
t2 $(15 \%)$ & 3,40 \\
t3 $(20 \%)$ & 3,32 \\
t4 (25\%) & 3,44 \\
t5 (30\%) & 3,40 \\
\hline
\end{tabular}

Sumber: Data primer 2019

Rasa Iwel Latan dengan penambahan tepung kedelai dengan aras perlakuan t1 sampai t5 yaitu 3,32 sampai 3,44 yang termasuk dalam kategori agak suka. Rasa yang dihasilkan dari setiap aras perlakuan yaitu manis dan sedikit gurih. Rasa manis didapatkan dari penambahan gula dan labu, untuk rasa gurih didapatkan dari penambahan kelapa parut dan tepung kedelai. Berdasarkan rata-rata tingkat kesukaan terhadap rasa perlakuan yang paling disukai adalah $\mathrm{t} 4$. 


\begin{tabular}{cc}
\hline Tabel 7. Penambahan Tepung Kedelai & \\
\hline Perlakuan Penambahan Tepung Kedelai dari Berat & $\begin{array}{c}\text { Rata-rata Hasil Uji Organoleptik secara } \\
\text { Keseluruhan Bahan }\end{array}$ \\
t1 (10\%) & 3,40 \\
t2 $(15 \%)$ & 3,52 \\
t3 $(20 \%)$ & 3,33 \\
t4 (25\%) & 3,57 \\
t5 (30\%) & 3,21 \\
\hline
\end{tabular}

Sumber: Data primer 2019

Overall pada Iwel Latan dengan penambahan tepung kedelai mempunyai nilai rata-rata dengan aras perlakuan t1 sampai t5 3,21 sampai 3,57 yang termasuk dalam kategori agak suka sampai suka. Berdasarkan rata-rata overall Iwel Latan perlakuan yang paling disukai adalah $\mathrm{t} 4$.

\section{Kandungan Zat Gizi}

Produk Iwel Latan terpilih selanjutnya dianalisis kandungan gizinya dengan analisis proksimat Pusat Studi Pangan dan Gizi Universitas Gadjah Mada. Kandungan zat gizi produk terpilih disajikan pada tabel 3.

Tabel 3.Kandungan Zat Gizi Iwel Latan dalam $100 \mathrm{~g}$.

\begin{tabular}{cccc}
\hline No & Parameter & $\begin{array}{c}\text { Satuan } \\
\text { (Berat Basah) }\end{array}$ & Hasil Uji rata-rata \\
\hline 1 & Kadar air & $\%$ & 40,71 \\
2 & Kadar abu & $\%$ & 1,60 \\
3 & Protein & $\%$ & 9,39 \\
4 & Lemak & $\%$ & 3,89 \\
5 & Karbohidrat & $\%$ & 44,40 \\
\hline
\end{tabular}

Sumber: Data primer 2019

Berdasarkan tabel 3. Hasil uji kandungan zat gizi Iwel Latan menunjukkan bahwa kadar air pada perlakuan t4 didalam 100 gram bahan yaitu 40,71\%, kadar abu 1,60\%, protein 9,39\%, lemak 3,89\%, dan karbohidrat $44,40 \%$. Selanjutnya kandungan makronutrient dalam 1 porsi (100 gram) produk iwel latan adalah energi sebesar 250,17 kkal, yang di estimasi dari penjumlahan +4 kkal (kadar protein) +9 kkal (kadar lemak) +4 kkal (kadar karbohidrat).

\section{Daya Terima Konsumen}

Uji daya terima dilakukan untuk mengetahui tingkat konsumsi atau daya terima konsumen ( ibu hamil) terhadap produk Iwel Latan sebagai alternatif makanan tambahan untuk ibu hamil yang akan diberikan dengan menggunakan metode penimbangan sisa makanan (Kemenkes RI,2013). Hasil rata-rata daya terima Iwel Latan dapat dilihat pada Gambar 2.

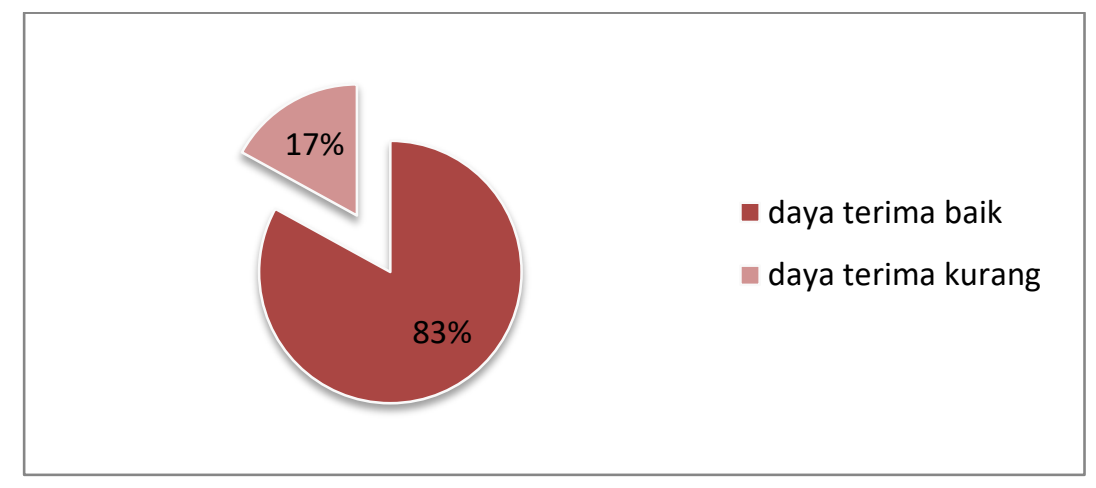

Gambar 2. Diagram Pie Daya Terima Iwel Latan

Daya terima ibu hamil yang digunakan sebagai panelis dalam uji daya terima ini adalah ibu hamil trimester II dan III sebanyak 30 orang. Dari 30 orang ibu hamil terdapat 25 ibu hamil (83\%) yang dapat menerima dengan baik ( $>80 \%$ habis dimakan) dan 5 ibu hamil $(17 \%)$ dengan daya terima kurang baik. $(<80 \%$ habis dimakan) 1 porsi Iwel Latan yang diberikan pada pada saat daya terima adalah 100 gram yang terdiri dari 3 potong Iwel Latan berukuran sedang. Porsi Iwel Latan yang diberikan dapat dilihat pada Gambar 3. 


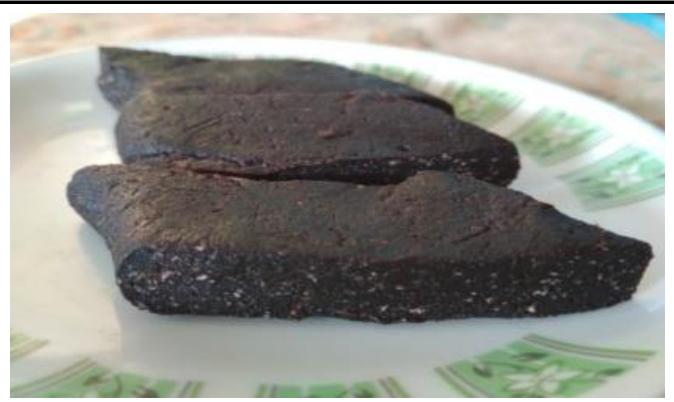

Gambar 3. Porsi Iwel Latan

\section{PEMBAHASAN \\ Sifat Organoleptik \\ Warna Iwel Latan dengan Penambahan Tepung Kedelai}

Hasil uji statistik menunjukkan bahwa probabilitas warna Iwel Latan adalah 0.965

( $p>0,05)$ yang dapat diartikan bahwa penambahan tepung kedelai pada Iwel Latan tidak memiliki pengaruh nyata terhadap warna Iwel Latan. Berdasarkan hasil uji organoleptik dapat diketahui bahwa warna Iwel Latan pada aras perlakuan t1 sampai t5 berada dalam kategori suka.

Warna yang dihasilkan Iwel Latan pada penelitian ini adalah didominasi oleh warna hitam dari bahan dasar tepung beras ketan hitam dengan campuran sedikit bintik-bintik berwarna coklat yang dihasilkan dari penambahan tepung kedelai dan labu kuning. Labu kuning mengandung senyawa karetonoid yaitu betakaroten. Menurut (Prasbini dkk,2009 dalam Hanggara dkk,2016) pemanasan pada bahan pangan yang mengandung karoten menyebabkan perubahan warna karoten karena adanya panas yang menginduksi perubahan struktur konjugasi karoten sehingga proporsi warna kuning menurun dan kuning kecoklatan meningkat (Hanggara dkk,2016).

Penambahan tepung kedelai juga dapat mempengaruhi warna produk menjadi warna kuning kecoklatan. Warna kuning kecoklatan pada kedelai berasal dari pigmen flavonoid yang berwarna kuning sehingga menghasilkan warna yang lebih gelap. Selain itu, tepung kedelai juga mengandung protein tinggi yang dapat memungkinkan terjadinya reaksi pencoklatan (Parinduri dkk,2016).

Pembentukan warna coklat merupakan reaksi pencoklatan non enzimatis yang disebabkan oleh reaksi Maillard. Menurut (Kusnandar,2010 dalam Hanggara dkk,2016) reaksi pencoklatan non enzimatis terjadi bila dalam pangan terdapat gula pereduksi dan senyawa yang mengandung gugus amin sehingga menghasilkan pigmen melanoidin yang bertanggung jawab atas pembentukan warna coklat yang dipacu oleh pemanasan pada suhu tinggi (Hanggara dkk,2016).

\section{Aroma Iwel Latan dengan Penambahan Tepung Kedelai}

Aroma pada makanan dapat menjadi daya tarik tersendiri dalam menentukan rasa enak atau tidak enak dalam suatu produk makanan. Aroma lebih banyak dipengaruhi oleh indera penciuman (Winarno,2004).

Hasil uji statistik menunjukkkan bahwa probabilitas aroma Iwel Latan adalah 0.127 (p > $\square 0,05$ ) yang dapat diartikan bahwa penambahan tepung kedelai pada Iwel Latan tidak memiliki pengaruh nyata terhadap aroma Iwel Latan.

Aroma khas dodol atau bahan makanan semi basah lainnya, yang pada penelitian ini adalah Iwel, aroma khas dipengaruhi oleh penambahan bahan seperti tepung beras ketan, santan/kelapa, dan gula merah. Bahan-bahan tersebut terdapat komponen volatile (komponen yang mudah menguap) yang berfungsi sebagai prekursor aroma dan selama proses pemanasan terbentuk secara kompleks sehingga menghasilkan aroma yang khas (Taswin dkk,2018).

Aroma yang dihasilkan Iwel Latan pada setiap perlakuan yaitu aroma khas dari tepung kedelai sehingga membuat aroma Iwel Latan berbeda dengan Iwel yang dibuat pada umumnya. Penambahan tepung kedelai membuat aroma Iwel Latan menjadi lebih gurih dan sedikit langu (off flavor).

\section{Tekstur Iwel Latan dengan Penambahan Tepung Kedelai}

Tekstur dan konsisten suatu bahan akan mempengaruhi citarasa yang ditimbulkan oleh bahan tersebut. Perubahan tekstur dari suatu bahan dapat mengubah rasa dan bau yang timbul karena dapat 
mempengaruhi kecepatan timbulnya rangsangan dari sel reseptor olifaktori dan kelenjar air liur (Winarno,2004).

Hasil uji statistik menunjukkkan bahwa probabilitas tekstur Iwel Latan adalah $0.004(\mathrm{p}<0,05)$ yang dapat diartikan bahwa penambahan tepung kedelai pada Iwel Latan memiliki pengaruh nyata terhadap tekstur Iwel Latan. Berdasarkan hasil uji organoleptik dapat diketahui bahwa tekstur iwel latan pada aras perlakuan $\mathrm{t} 1, \mathrm{t} 3$, dan $\mathrm{t} 5$ berada dalam kategori agak suka, sedangkan untuk $\mathrm{t} 2$ dan $\mathrm{t} 4$ berada dalam kategori suka.

Tekstur yang dihasilkan Iwel Latan yaitu lembut, padat, dan agak lengket. Tekstur Iwel Latan berbeda pada aras perlakuan t1 sampai t5, dimana semakin banyak penambahan tepung kedelai, tekstur Iwel Latan menjadi lebih lembut.

Menurut Haryadi (2006) komponen utama dodol/iwel ialah tepung beras ketan, yang dimana pada saat proses pemanasan pati yang terkandung didalam tepung menyerap air dalam bentuk pasta yang kental, dan pada saat didinginkan akan membentuk masa yang kenyal. Tekstur yang dihasilkan Iwel dipengaruhi oleh penambahan tepung beras ketan, sehingga menghasilkan Iwel dengan tekstur yang lembut, padat dan agak lengket.

Tekstur iwel latan yang disukai oleh panelis berdasarkan uji hedonik yaitu iwel latan dengan penambahan tepung kedelai sebanyak $25 \%$. Semakin banyak penambahan tepung kedelai tekstur Iwel Latan menjadi lebih lembut, terbukti pada saat uji hedonik panelis menyukai Iwel Latan dengan penambahan tepung kedelai sebanyak $25 \%$.

Menurut (Virgo,2007 dalam Parinduri dkk,2016) Penambahan tepung kedelai juga dapat mempengaruhi tekstur. Tepung kedelai yang ditambahkan menyebabkan tekstur disukai oleh panelis, karena kandungan pati dan protein yang terdapat pada tepung kedelai berperan mengikat air sehingga mempengaruhi pembentukan tekstur produk (Parinduri dkk,2016).

\section{Rasa Iwel Latan dengan Penambahan Tepung Kedelai}

Rasa merupakan salah satu faktor yang sangat berpengaruh dalam menentukan mutu suatu makanan. Rasa juga merupakan suatu indikator penilaian produk pangan yang sangat diperhatikan oleh konsumen. Rasa yang dihasilkan oleh produk pangan dapat berasal dari makanan itu sendiri atau penambahan dari bahan makanan lain pada saat proses pembuatan.

Hasil uji statistik menunjukkkan bahwa probabilitas rasa Iwel Latan adalah $0.989 \quad(\mathrm{p}>\square 0,05)$ yang dapat diartikan bahwa penambahan tepung kedelai pada Iwel Latan tidak memiliki pengaruh nyata terhadap rasa Iwel Latan.

Rasa yang dihasilkan Iwel Latan pada setiap aras perlakuan yaitu manis dan gurih. Rasa manis didapatkan dari penambahan gula merah sebagai bahan pencampur tepung pada saat proses pembuatan, dan rasa gurih didapatkan dari penambahan kelapa parut dan tepung kedelai. Menurut Haryadi (2006) penambahan gula merah berfungsi sebagai pemberi rasa manis dan membantu dalam pembentukan tekstur sehingga dodol/iwel dapat menjadi lebih legit dan liat. Fungsi lain dari penambahan gula menurut Wahyuningsih (2004) gula memiliki peranan untuk memperoleh aroma, serta untuk memperoleh tekstur dengan konsistensi tertentu yang dikehendaki.

\section{Kandungan Zat Gizi \\ Kadar Air}

Pengujian kadar air dilakukan untuk mengetahui total air yang terkandung didalam iwel latan dengan penambahan tepung kedelai. Kadar air didalam suatu bahan pangan sangat penting untuk mempertahankan daya simpan dari bahan pangan tersebut (Syarief dkk,1988 dalam Alyanti dkk,2017).

Air merupakan komponen penting dalam bahan makanan karena mempengaruhi penampakan, tekstur, dan citarasa makanan. Kandungan air dan aktivitas air mempengaruhi perkembangan reaksi pembusukan secara kimia dan mikrobiologi dalam makanan (Deman,1997 dalam Alyanti dkk,2017).

Menurut Musaddad dan Hartuti, (2003) dalam penelitian Hanggara dkk (2016) yang membahas tentang Sifat Kimia dan Sensori Dodol Labu Kuning menyebutkan bahwa syarat mutu kadar air untuk makanan semi padat (intermediate moisture food) sebesar 10-40\%. Sehingga hasil uji kadar air air iwel latan lebih tinggi dari standar kadar air untuk makanan semi basah. 
Kadar air iwel latan yang lebih tinggi dipengaruhi oleh penambahan labu kuning pada pembuatan iwel latan. Hal ini dikarenakan labu kuning yang mempunyai kadar air yg cukup tinggi yaitu 86.6 per 100 gram bahan. Proses pengukusan membuat kadar air dari labu kuning menjadi lebih tinggi, hal ini berkaitan dengan proses pembuatan iwel latan yang dibuat melalui proses pengukusan. Pengukusan merupakan proses pemasakan dengan menggunakan medium uap air panas yang dihasilkan oleh air mendidih. Pada proses pengukusan, matrik jaringan sayuran cenderung menyerap air sehingga kandungan airnya relative lebih tinggi dari sayuran segar (Aisyah dkk, 2014 dalam Hanggara dkk,2016).

\section{Kadar Abu}

Bahan pangan mengandung kadar abu atau komponen anorganik dalam jumlah yang berbeda. Abu disusun oleh berbagai jenis mineral dan komposisi yang beragam tergantung pada jenis dan sumber bahan pangan. Kandungan abu dan mineral pada bahan pangan menjadi sangat penting untuk mendapatkan abu atau mineral yang diperlukan oleh tubuh (Andarwulan dkk, 2011).

Sebagian besar bahan makanan, yaitu $96 \%$ terdiri dari bahan organik dan air, sisanya terdiri dari unsurunsur mineral. Unsur mineral tersebut dikenal sebagai zat organik atau unsur kadar abu. Dalam proses pembakaran, bahan-bahan organik terbakar tetapi zat organiknya tidak, sehingga karena itulah disebut abu. Pengujian kadar abu dilakukan untuk mengetahui total abu yang terkandung didalam produk pangan (Hanggara dkk,2016).

Berdasarkan hasil uji kesukaan panelis pada aras perlakuan terbaik produk yang terpilih kemudian akan dilakukan analisis kadar abu. Hasil uji kadar abu iwel latan yaitu 1,60\% jika dibandingkan dengan syarat mutu dodol menurut SNI yang dimana nilai maksimal abu dodol yaitu 1,5\% maka kadar air iwel latan lebih tinggi dibandingkan dengan standar SNI.

\section{Protein}

Protein merupakan suatu zat gizi yang amat penting bagi tubuh, karena zat ini selain berfungsi sebagai bahan bakar dalam tubuh juga berfungsi sebagai zat pembangun dan pengatur. Protein merupakan salah satu kelompok bahan makanan yang terdapat dalam jumlah yang besar (makronutrient). Selain itu, protein juga berfungsi sebagai pembentukan sel-sel baru pengganti sel-sel pada jaringan yang rusak dan sebagai sumber energi (Hanggara dkk,2016).

Kadar protein menurut SNI dodol yaitu minimal 3\%. Berdasarkan hasil uji kadar protein dapat diketahui bahwa kadar protein iwel latan lebih tinggi dari standar SNI dodol. Dibandingkan dengan kandungan protein pada biskuit PMT ibu hamil per kemasan biskuit hanya mengandung 2 gram protein.

Hasil uji proksimat Iwel Latan mengandung 9,39\% protein, sehingga protein Iwel Latan lebih tinggi dibandingkan dengan biskuit PMT ibu hamil. Kadar protein Iwel Latan telah memenuhi standar sehingga produk iwel latan layak di konsumsi untuk ibu hamil sebagai snack atau pemberian makanan tambahan yang tinggi protein.

Penambahan tepung kedelai didalam proses pembuatan dapat menjadi faktor penyebab terjadinya peningkatan protein pada iwel latan. Kedelai memiliki kandungan gizi yang tinggi diantara kacangkacangan lainnya. Kadar protein kedelai yaitu 40,4 gram dalam 100 gram bahan (Mahmud dkk,2009).

\section{Lemak}

Lemak terdapat pada semua bahan pangan dengan kandungan yang berbeda-beda. Lemak dan minyak merupakan zat makanan yang penting untuk menjaga kesehatan tubuh manusia. Lemak juga berfungsi sebagai sumber energi yang lebih efektif dibanding dengan karbohidrat.

Lemak pada dodol berasal dari kelapa parut yang memiliki peran sebagai pemberi flavor, melarutkan tepung dan gula dan mengurangi sifat melekatnya bahan penyusun dodol lainnya (Taswin dkk,2018). Syarat mutu berdasarkan SNI dodol yaitu kadar lemak minimum 7\%. Sehingga, hasil uji kadar lemak iwel latan lebih rendah dibandingkan standar mutu dodol. Faktor yang menyebabkan kadar lemak iwel latan lebih rendah dibandingkan standar mutu SNI dodol yaitu karena pada proses pembuatan iwel latan, jenis minyak atau kelapa yang digunakan yaitu hanya menggunakan kelapa parut, tanpa menggunakan santan kelapa. Sehingga lemak atau minyak yang dihasilkan menjadi lebih sedikit dibandingkan dodol yang dimasak dengan santan kelapa atau tambahan minyak. Dalam proses pembuatan iwel latan kelapa parut hanya ditambahkan sebanyak 20 gram didalam 100 gram bahan. 


\section{Karbohidrat}

Karbohidrat mempunyai fungsi utama menyediakan kebutuhan untuk energi tubuh. Namun fungsi karbohidrat bukan hanya sebagai sumber energi akan tetapi memiliki fungsi lain didalam keberlangsungan proses metabolisme dalam tubuh (Taswin dkk, 2016).

Berdasarkan hasil uji kesukaan panelis pada aras perlakuan terbaik, produk yang terpilih akan dilakukan uji kadar karbohidrat. Hasil uji kadar karbohidrat iwel latan yaitu 44,40\%. Menurut standar SNI untuk karbohidrat dodol didalam 100 gram bahan yaitu minimal 40\%. Dengan demikian, hasil uji kadar karbohidrat iwel latan lebih tinggi dibandingan standar mutu untuk kadar karbohidrat dodol.

Kandungan karbohidrat didalam biskuit PMT untuk ibu hamil mengandung 13 gram karbohidrat, sehingga hasil uji proksimat untuk karbohidrat Iwel Latan $(44,40 \%)$ lebih tinggi dibandingkan dengan karbohidrat didalam biskuit PMT ibu hamil.

Penggunaan bahan dasar tepung beras ketan sebagai bahan utama didalam pembuatan iwel latan menjadi sumber karbohidrat pada iwel latan. Sehingga iwel latan dapat dijadikan snack atau PMT yang padat gizi dengan karbohidrat yang cukup untuk makanan tambahan ibu hamil.

\section{Energi}

Makanan adalah sumber energi bagi manusia. Sumber energi utama bagi tubuh manusia adalah karbohidrat, protein, dan lemak. Penggunaan simpanan energi yang digunakan tergantung dengan aktivitas fisik yang dilakukan.

Energi yang dihasilkan oleh tubuh manusia dinyatakan dalam kalori. Penentuan jumlah kalori di dalam iwel latan diestimasi dari penjumlahan kalori kadar protein, kadar lemak dan kadar karbohidrat. Sehingga didapatkan hasil energi dari iwel latan adalah 250,17 kkal.

Kandungan energi total biskuit PMT ibu hamil mengandung 95 kkal, apabila dibandingkan dengan energi yang terdapat dalam Iwel Latan, energi Iwel Latan lebih tinggi dari biskuit PMT ibu hamil. Sehingga produk Iwel Latan dapat dijadikan rekomendasi pemberian makanan tambahan untuk ibu hamil dengan kandungan zat gizi yang cukup tinggi.

\section{Daya Terima Konsumen}

Uji daya terima dilakukan untuk mengetahui tingkat konsumsi atau daya terima konsumen ( ibu hamil) terhadap produk Iwel Latan sebagai alternatif makanan tambahan untuk ibu hamil yang akan diberikan dengan menggunakan metode penimbangan sisa makanan (Kemenkes RI,2013).

Daya terima ibu hamil yang digunakan sebagai panelis dalam uji daya terima ini adalah ibu hamil trimester II dan III sebanyak 30 orang. Dari 30 orang ibu hamil terdapat 25 ibu hamil (83\%) yang dapat menerima dengan baik (>80\% habis dimakan) dan 5 ibu hamil $(17 \%)$ dengan daya terima kurang baik. $(<80 \%$ habis dimakan $)$.

Hasil daya terima pada 25 orang ibu hamil dengan daya terima baik memberikan tanggapan bahwa produk Iwel Latan memiliki rasa yang enak dan manis yang ditonjolkan dari gula merah, dengan penambahan rasa yang sedikit gurih dirasakan dari penambahan kelapa parut dan tepung kedelai. Konsumen juga menyatakan bahwa tekstur dari iwel latan cukup lembut dan legit.

Dari 5 orang ibu hamil dengan daya terima yang kurang baik menyatakan bahwa iwel latan sudah cukup enak namun merasakan agak sedikit asin. Selain itu juga mereka sebelumnya sudah makan terlebih dahulu, sehingga merasa masih kenyang, dan tidak bisa menghabiskan 1 porsi Iwel Latan (100 g) yang diberikan. Satu porsi Iwel Latan terdiri dari 3 potong Iwel Latan yang berukuran sedang.

Melihat respon baik dari 30 orang ibu hamil terhadap daya terima produk Iwel Latan dapat memberikan peluang yang positif untuk kedepannya dijadikan sebagai makanan tambahan ibu hamil yang padat akan zat gizi, karena kandungan zat gizi dari Iwel Latan yang cukup tinggi dan telah memenuhi standar pemberian makanan tambahan untuk ibu hamil. 


\section{KESIMPULAN}

Penambahan tepung kedelai pada Iwel Latan memberikan pengaruh yang nyata terhadap tesktur Iwel Latan $(\mathrm{p}<0,005)$ sedangkan untuk warna, aroma, dan rasa tidak memberikan pengaruh yang nyata ( $<<0,005$ ). Hasil uji kandungan zat gizi (uji proksimat) Iwel Latan telah memenuhi standar SNI untuk makanan semi basah. Kandungan zat gizi Iwel Latan yaitu kadar air 40,71\%, kadar abu 1,60\%, protein 9,39\%, lemak 3,89\%, karbohidrat 44,40\% dan energi 250,17 Kkal. Hasil uji daya terima Iwel Latan dapat diterima dengan baik oleh konsumen ibu hamil. Dengan jumlah ibu hamil dengan daya terima baik sebanyak 25 orang ibu hamil (83\%) dan daya terima kurang sebanyak 5 orang ibu hamil (17\%).

\section{SARAN}

Perlu adanya penelitian lebih lanjut mengenai masa simpan iwel. Produk Iwel Latan yang berbahan pangan lokal dapat dijadikan sebagai PMT untuk ibu hamil, dengan pemberian 2 kali sehari.

\section{DAFTAR PUSTAKA}

Alyanti, Patang, Nurmila. 2017. Analisis Pembuatan Dodol Berbahan Baku Tepung Melinjo dan Tepung Beras Ketan. Jurnal Pendidikan Teknologi Pertanian. Vol. 3

Andarwulan, N., Kusnandar, F, Herawati, D. 2011. Analisis Pangan. Dian Rakyat. Jakarta.

Hanggara, H.,Sussi, A., Sri, S. 2016. Pengaruh Formulasi Pasta Labu Kuning dan Tepung Beras Ketan Putih Terhadap Sifat Kimia dan Sensori Dodol. Jurnal Teknologi Hasil Pertanian. Vol 21

Haryadi. 2006. Teknologi Pengolahan Beras. Gadjah Mada Uneversity. Press.

Kementerian Kesehatan Republik Indonesia, 2012. Panduan Penyelenggaraan Pemberian Makanan Tambahan Pemulihan Bagi Balita Gizi Kurang dan Ibu Hamil KEK (Bantuan Operasional Kesehatan). Jakarta: Kemenkes RI.

Kementerian Kesehatan Republik Indonesia, 2013. Pedoman Pelayanan Gizi Rumah Sakit. Jakarta : Kemenkes RI

Kementerian Kesehatan Republik Indonesia. 2017. Petunjuk Teknis Pemberian Makanan Tambahan Balita, Anak Sekolah, Ibu Hamil. Jakarta: Kemenkes RI.

Kementerian Kesehatan Republik Indonesia, 2018. Pokok-Pokok Hasil Riskesdas Indonesia 2018, Jakarta: Kemenkes RI.

Mahmud,N.A. Zulfianto., Mien., Hermana. 2009. Tabel Komposisi Pangan Indonesia. Jakarta : Elex Media Komputindo.

Parinduri, M., Herla, R., Lasma, N.L. 2016. Pengaruh Perbandingan Tepung Kedelai Germinasi dengan Tapioka dan Perbandingan Daging Ayam dengan Bubur Rebung Terhadap Mutu Nugget Rebung. Jurnal Rekayasa Pangan dan Pertanian. Vol 4

Rani, H., Zulfahmi., Yatim R. Widodo. 2013. Optimasi Proses Pembuatan (Tepung) Kedelai. Jurnal Penelitian Pertanian Terapan. Vol 13.

Standar Nasional Indonesia 1992. Standar Mutu Dodol. Badan Standarisasi Nasional Indonesia. 012986-1192. Jakarta.

Supariasa, I.D.N., Bachyar, B., Ibnu, F. 2012. Penilaian Status Gizi. Penerbit Buku Kedokteran EGC. Jakarta.

Taswin, N.C., La Karimuna., Nur, A. 2018. Kajian Formulasi Bubur Jagung (Zea mays L.) dan Tepung Daun Katuk (Sauropus androgynus L.) Pada Pembuatan Dodol Jagung Terhadap Nilai Gizi dan Sifat Organoleptik. Jurnal Sains dan Teknologi Pangan. Vol 3

Wahyuningsih, W. 2004. Analisa Strategi Pemasaran Industri Kecil Permen Karamel susu di Daerah Pengalengan, Jawa Barat. Tesis Pasca Sarjana Institut Pertanian Bogor. Bogor.

Winarno, FG. 2004. Kimia Pangan dan Gizi. PT Gramedia Pustaka Utama. Jakarta. 